\title{
Effects of Tumor Necrosis Factor Blocker on Salicylate-Induced Tinnitus in Mice
}

\author{
Juen-Haur Hwang ${ }^{1,2}$ \\ David Chang-Wei Huang ${ }^{3}$ \\ Yin-Chang Lu ${ }^{4}$ \\ Wei-Shiung Yang ${ }^{5}$ \\ Tien-Chen Liu ${ }^{4}$
}

\begin{abstract}
Objective: Neuroinflammation is considered a novel mechanism for acute tinnitus. Here, we investigated the effects of a tumor necrosis factor (TNF) blocker on the gene expression of inflammatory-cytokine in the cochlea in a tinnitus animal model. Methods: Enbrel ${ }^{\circledR}(30 \mathrm{mg} / \mathrm{kg}$, intraperitoneally (i.p.)) were administrated to the mice with the salicylate induced tinnitus for 3 days. Tinnitus score and mRNA expression levels of TNFR1, TNFR2, and N-methyl-d-aspartate receptor subunit 2B (NR2B) and its downstream regulatory element antagonist modulator (DREAM) in the cochlea of mice were measured and compared to the control. Results: The tinnitus score significantly decreased in the Enbrel ${ }^{\circledR}$ treated group. The mRNA levels of both TNFR1 and TNFR2 were significantly lower in the treatment than in the control group. The mRNA levels of NR2B and DREAM followed a similar trend. Conclusion: we found that treatment with $30 \mathrm{mg} /$ $\mathrm{kg}$ Enbrel ${ }^{\circledR}$ decreased salicylate-induced behavior associated with tinnitus and reduced the mRNA expression levels of TNFR1/R2, NR2B, and DREAM in the cochlea of mice. These findings supported the hypothesis that neuroinflammation might be a novel mechanism for salicylate-induced tinnitus.
\end{abstract}

Keywords: cochlea, gene expression, salicylate, tinnitus, TNF blocker.

'Department of Otolaryngology, Dalin Tzu Chi Hospital, Buddhist Tzu Chi Medical Foundation, Chiayi, Taiwan

${ }^{2}$ School of Medicine, Tzu Chi University, Hualien, Taiwan

${ }^{3}$ Department of Otolaryngology, Kuang-Tien General Hospital, Taichung, Taiwan

${ }^{4}$ Department of Otolaryngology, National Taiwan University Hospital, Taipei, Taiwan

${ }^{5}$ Graduate Institute of Clinical Medicine, College of Medicine, National Taiwan University, Taipei, Taiwan

Send correspondence to:

Tien-Chen Liu

Department of Otolaryngology, National Taiwan University Hospital Taipei, Taiwan. E-mail: liuent@ntu.edu.tw

Paper submitted to the ITJ-EM (Editorial Manager System) on February 21, 2017;

and accepted on March 14, 2017. 


\section{INTRODUCTION}

Tinnitus is the perception of sound in the absence of acoustic stimulation. Tinnitus can be perceived in one or both ears or in the head, and is usually described symptomatically as being able to hear a ringing noise. Usually, tinnitus and hearing loss occur together. To date, no effective treatment that reliably reduces the sensation of tinnitus is available, although some medications appear to be effective in certain patients ${ }^{1}$. Currently, finding a pharmacological solution for tinnitus is a demanding and challenging task.

Salicylate-induced tinnitus in mice is a popular animal model for studying the condition ${ }^{2}$. High doses of sodium salicylate (250-300 mg/kg, intraperitoneally (i.p.)) are known to elevate hearing thresholds, and reliably induce tinnitus ${ }^{2}$. Based on results from a human ${ }^{3}$ and animals studies ${ }^{4,5}$, neural inflammation may be a novel mechanism in tinnitus. It was found that the expression levels of the $\mathrm{N}$-methyl-d-aspartate receptor subunit 2B (NR2B) gene increased moderately in the cochlea and midbrain during salicylate-induced tinnitus ${ }^{4}$. Further, genes for tumor necrosis factor (TNF)- $\alpha$ and interleukin (IL)-1 $\beta$ were also up-regulated significantly in the cochlea and inferior colliculus (IC) in salicylate-induced tinnitus5. We hypothesized that proinflammatory cytokines might lead to tinnitus directly and/or via modulating NR gene expression 5 .

Etanercept $\left(\right.$ Enbrel $\left.^{\circledR}\right) \quad$ induced regulatory macrophages in an Fc region-dependent manner and contributed to the resolution of inflammation ${ }^{6,7}$. It was the first biological disease-modifying anti-rheumatic drug and the first TNF inhibitor to be approved for use in rheumatic diseases ${ }^{8}$. Enbrel ${ }^{\circledR}$ could prevent retinal ganglion cell loss in a rat model of glaucoma ${ }^{9}$, and ameliorate injury-induced neuropathic pain in sciatic nerve crush injury models ${ }^{10}$. In addition, Enbrel ${ }^{\circledR}$ was expected to have a beneficial effect on neurodegenerative diseases and neurogenic pain ${ }^{11}$.

However, the effects of the TNF blocker on salicylate-induced tinnitus are still unclear. According to our hypothesis, these blockers can act on the inflammation pathway and potentially attenuate or stop tinnitus. Therefore, in this study, we investigated the outcome of treatment with Enbrel ${ }^{\circledR}$ and its interaction with NR2B and downstream regulatory element antagonist modulator DREAM in the cochlea of mice with salicylateinduced tinnitus.

\section{ANIMALS AND METHODS}

\section{Animals}

Thirty 3-month-old male C57BL/6 mice were randomly and equally divided into TNF-blocker (Enbrel ${ }^{\circledR}$, $30 \mathrm{mg} / \mathrm{kg})$ treated $(n=15)$ and saline-treated control $(n=$ 15) groups. All methods for animal care and experiments were carried out in accordance with relevant guidelines and regulations of the Institutional Animal Care and Use Committee (IACUC). In addition, all experimental protocols were approved by the National Taiwan University College of Medicine and College of Public Health IACUC (No. 20110467)

\section{Hearing threshold testing}

Auditory brain responses (ABR) to click sounds at $4 \mathrm{kHz}, 10 \mathrm{kHz}$, and $16 \mathrm{kHz}$ were performed 2 days before tinnitus training/conditioning and immediately after the end of the study.

\section{Behavioural measurement of tinnitus score}

All mice were trained to perform an active avoidance task, which was performed in a conditioning box with an electrical floor and a climbing pole, according to the design by Guitton et al. ${ }^{12}$.

\section{Conditioning to the task}

The conditioning paradigm consisted of 6 sessions performed daily for 5 days. Each session lasted for 15-20 minutes, and there were 10 trials per session. Inter-trial intervals lasted for at least 1 minute each. For each trial, the conditioning stimulus was a $50 \mathrm{~dB}$ sound pressure level (SPL) pure tone with a frequency of $10 \mathrm{kHz}$ for $3 \mathrm{~s}$. The unconditioned stimulus was a $3.7 \mathrm{~mA}$ electric footshock for $30 \mathrm{~s}$, as described in the protocol used by Guitton et al. ${ }^{12}$, achieved by adjusting the electric voltage in Copper wire with fixed resistance on the floor. Time between conditioned and unconditioned stimuli was $1 \mathrm{~s}$. The mice would climb up through the pole into a safe area after the combined conditioned and unconditioned stimuli. Electrical shocks were stopped by the experimenter when the animal climbed correctly. The "true-positive" score was the level of performance assessed by the number of times the mice climbed correctly in response to sound. Mice were considered to be conditioned when the "truepositive" score reached at least $80 \%$ in three consecutive sessions. Only conditioned mice were selected for the tinnitus experiments.

\section{Induction and testing of tinnitus}

Once conditioned, the mice rested for 1 day. The following day, a tinnitus baseline test was measured $1 \mathrm{~h}$ before i.p. injection with $300 \mathrm{mg} / \mathrm{kg}$ sodium salicylate. Two treatment strategies were used as follows: i.p. injection of $30 \mathrm{mg} / \mathrm{kg}$ Enbre ${ }^{\circledR}$ or saline $1 \mathrm{~h}$ after the sodium salicylate injection. An active avoidance task of one session with 10 trials was performed $1 \mathrm{~h}$ after treatment for 3 days. To avoid changes attributable to hearing loss induced by salicylate (about 10 to $20 \mathrm{~dB}$ during salicylate injections, as revealed by our preliminary experiment), the intensity of sound that elicited the behavioural responses was increased to $70 \mathrm{~dB}$ SPL in both groups. By doing so, the sound sensation levels of all mice in the study were similar. During testing, first, a sound of $3 \mathrm{~s}$ duration was given in each trial, and the mice were observed for another $5 \mathrm{~s}$ to see whether they would climb up the pole. The mice were returned to the floor for observations if they stayed on the safe area for more than $10 \mathrm{~s}$ (true-positive). If the mice did not climb up the pole, an electrical shock was given by the experimenter to remind the mice to 
climb up. Again, the mice were returned to the floor for observations if they stayed on the safe area for more than $10 \mathrm{~s}$. Finally, observed the total number (false-positive or tinnitus score) of times the mice climbed during the intertrial silent period of 1 minute for 10 trials.

\section{cochlea}

Sample isolation and RNA extraction from the

The mice were euthanized by decapitation to determine the gene expression levels of TNF receptor-1/2 (TNFR1/2) and NMDA receptor (NR2B) subunit and levels of DREAM in the cochlea.

The soft tissues of both cochleas were pooled together as one sample for each mouse and then the total RNA was isolated from the tissue homogenates of each sample using a modified Trizol protocol (Gibco BRL). Each sample was centrifuged at $12000 \mathrm{~g}$ for 10 minutes at $4^{\circ} \mathrm{C}$ and the clear supernatant was transferred to a new tube and incubated for 5 minutes at $15-30^{\circ} \mathrm{C}$ to permit the complete dissociation of nucleoprotein complexes. To each $\mathrm{ml}$ of Trizol reagent, $0.2 \mathrm{ml}$ of chloroform was added and the tube was shaken vigorously by hand for $15 \mathrm{~s}$, then incubated at $15-30^{\circ} \mathrm{C}$ for 2 minutes and centrifuged at $12000 \mathrm{~g}$ for 15 minutes at $4^{\circ} \mathrm{C}$. The aqueous phase was transferred to a new tube, $0.5 \mathrm{ml}$ of isopropyl alcohol per 1 $\mathrm{ml}$ Trizol reagent was added, and then it was incubated at $15-30^{\circ} \mathrm{C}$ for 10 minutes. This was followed by centrifuging at $12000 \mathrm{~g}$ for 10 minutes at $4^{\circ} \mathrm{C}$. The supernatant was separated and the RNA pellet was washed once with $1 \mathrm{ml}$ $75 \%$ ethanol. The sample was mixed by vortex and then centrifuged at $7500 \mathrm{~g}$ for 5 minutes at $4^{\circ} \mathrm{C}$. The new RNA pellet was air-dried, dissolved in 10-20 $\mu \mathrm{l}$ of RNase-free water, and incubated at $42^{\circ} \mathrm{C}$ for 5 minutes. RNA quality was assessed by Agilent Bioanalyzer 2100 , and the ratio of absorbance at $260 \mathrm{~nm}$ and $280 \mathrm{~nm}$ measured using the Nanodrop.

\section{Real-time quantitative polymerase chain reaction (RT-qPCR)}

The sequences of the primer and probe number used in this study are listed in Table 1. The primers and the probes were designed using Universal Probe Library (UPL) of Roche Applied Science (Indianapolis, IN, USA).

The $2 \mu \mathrm{g}$ of RNA was treated with DNase and then reverse transcribed into first-strand cDNA in a $20 \mu \mathrm{l}$ reaction volume using SuperScript III Reverse Transcriptase (Invitrogen, CA, USA). Quantitative realtime reverse transcription (RT)-PCR assays of cDNA were performed using a gene-specific double fluorescently labeled probe in an ABI Prism 7900 Sequence Detection System (Applied Biosystems) in accordance with the manufacturer's recommendations. The reactions' thermal cycle conditions were adjusted as 10 minutes initial setup at $95^{\circ} \mathrm{C}$, followed by 40 cycles, each of which consisted of $15 \mathrm{~s}$ denaturing at $95^{\circ} \mathrm{C}$ and 1 minute annealing/ extending at $60^{\circ} \mathrm{C}$. The relative mRNA expression level was determined by the $2-\Delta \mathrm{Ct}$ analysis method, and calculations were performed using the software provided by the manufacturer (Applied Biosystems). The expression levels of TNF-R1/2, NR2B, and DREAM were presented as relative ratios in comparison to the expression of $\beta$-actin.

\section{Statistical analysis}

Unless otherwise stated, all data are presented as either mean \pm standard deviation (SD) or boxplots including median, 75 and 25 percentile values. ' $n$ ' is the number of animals per experimental group. The statistical differences between means were compared either by Student's t-test and the median compared by MannWhitney U-test, depending on the distribution pattern of the variable, test by Shapiro-Wilk normality test, and sample size. $P$ values $<0.05$ were considered statistically significant.

Table 1. Primers and probes used in this study.

\begin{tabular}{|c|c|c|}
\hline Genes & Sequences of primers and probes $\left(5^{\prime}-3^{\prime}\right)$ & Amplicon size (bp) \\
\hline & F, CCGCAACGTCCTGACAAT & \\
\hline \multirow[t]{3}{*}{ TNFR1 } & R, GCCTCTCGATCTCGTGCT & 121 \\
\hline & Probe number: \# 12 & \\
\hline & F, TCTGAGTCTGGCCTCAT & \\
\hline \multirow[t]{3}{*}{ TNFR2 } & R, GGCTTCCGAGATGACAGAAC & 61 \\
\hline & Probe number: \# 12 & \\
\hline & F, TCTAAGGAAGGCCATTGAACC & \\
\hline \multirow[t]{3}{*}{ NR2B } & R, CCATGCAGCAAGAATTCAGA & 69 \\
\hline & Probe number: \# 68 & \\
\hline & F, TGGAGCTAAGACTCGGAAGG & \\
\hline \multirow[t]{3}{*}{ DREAM } & R, GCAATTGTCACTGGAGGTTTC & 77 \\
\hline & Probe number: \# 12 & \\
\hline & F, CTAAGGCCAACCGTGAAAAG & \\
\hline \multirow[t]{2}{*}{$\beta$-actin } & R, ACCAGAGGCATACAGGGA CA & 104 \\
\hline & Probe number: \# 64 & \\
\hline
\end{tabular}




\section{RESULTS}

\section{ABR hearing thresholds}

Figure 1 shows the $A B R$ hearing thresholds in both groups. In the control group, the pre-injection mean hearing thresholds were $35.7 \pm 3.6 \mathrm{~dB}(4 \mathrm{kHz}), 30.8 \pm$ $2.1 \mathrm{~dB}(10 \mathrm{kHz})$, and $37.7 \pm 3.7 \mathrm{~dB}(16 \mathrm{kHz})$, respectively. The post-injection mean hearing thresholds were $44.7 \pm$ $3.9 \mathrm{~dB}(4 \mathrm{kHz}), 38 \pm 3.1 \mathrm{~dB}(10 \mathrm{kHz})$, and $47.5 \pm 2.8 \mathrm{~dB}$ $(16 \mathrm{kHz})$, respectively. The post-injection mean hearing thresholds were significantly elevated compared to preinjection thresholds, being $4 \mathrm{kHz}(p=6.61 \mathrm{E}-07), 10 \mathrm{kHz}$ $(p=1.36 \mathrm{E}-07)$, and $16 \mathrm{kHz}(p=1.78 \mathrm{E}-08)$. Thus, 3 consecutive days of injection with $300 \mathrm{mg} / \mathrm{kg}$ sodium salicylate induced significant shifts in hearing thresholds.

In the treatment group, the pre-injection mean hearing thresholds were $33.9 \pm 3.4 \mathrm{~dB}(4 \mathrm{kHz}), 29.1 \pm 3.7$ $\mathrm{dB}(10 \mathrm{kHz})$, and $35.6 \pm 4.3 \mathrm{~dB}(16 \mathrm{kHz})$, respectively. The post-injection hearing thresholds were $35.4 \pm 3.4 \mathrm{~dB}(4$ $\mathrm{kHz}), 33.9 \pm 2.8 \mathrm{~dB}(10 \mathrm{kHz})$, and $39.9 \pm 4.3 \mathrm{~dB}(16 \mathrm{kHz})$, respectively. The post-injection mean hearing thresholds were slightly elevated from pre-injection thresholds for 4 $\mathrm{kHz}(\mathrm{p}=0.27), 10 \mathrm{kHz}(\mathrm{p}=0.001)$, and $16 \mathrm{kHz}(\mathrm{p}=$ 0.02). These results revealed that treatment with Enbrel ${ }^{\circledR}$ decreased the level of salicylate-induced shifts in ABR hearing thresholds.

Figure 2 shows the tinnitus scores for both the groups. The mean tinnitus scores at baseline and 3 days after i.p. injection with $300 \mathrm{mg} / \mathrm{kg}$ sodium salicylate were $4.9 \pm 2.7,19.5 \pm 7.5,24.7 \pm 12$, and $22.7 \pm 7.4$, respectively, in the control group, and $4.5 \pm 2.9,21.6$ $\pm 12.8,15.7 \pm 6.6$, and $15.1 \pm 5.1$, respectively, in the treatment group. Student's t-test revealed that treatment with Enbrel ${ }^{\circledR}$ significantly decreased salicylate-induced behaviour associated with tinnitus each day after i.p.

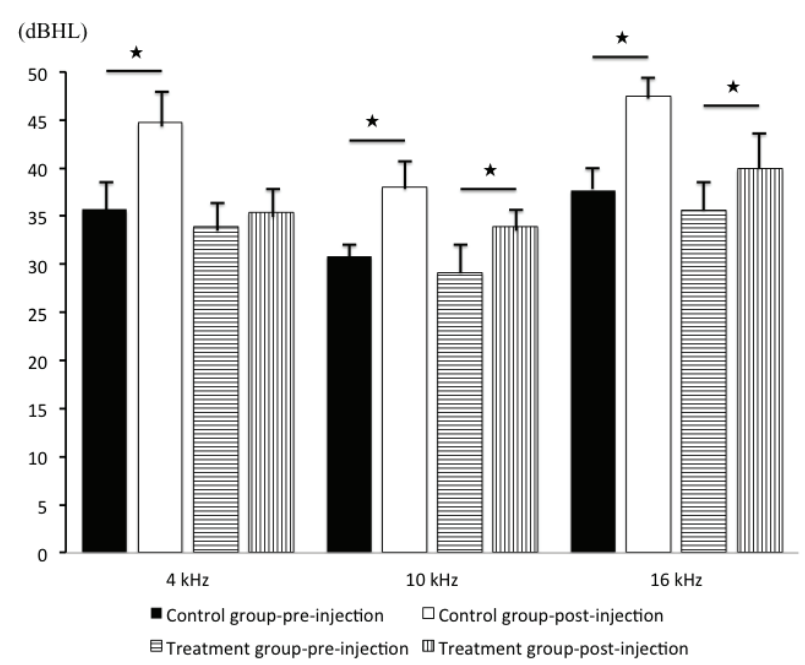

Figure 1: ABR hearing thresholds in both the groups. Consecutive 3 days of injection with $300 \mathrm{mg} / \mathrm{kg}$ sodium salicylate induced significant shift in the hearing thresholds ( $P$-values for frequency were $6.61 \mathrm{E}-07$ at $4 \mathrm{kHz}, 1.36 \mathrm{E}-07$ at $10 \mathrm{kHz}$, and $1.78 \mathrm{E}-08$ at $16 \mathrm{kHz}$, respectively). Treatment with Enbrel ${ }^{\circledR}$ decreased salicylate-induced shift in $A B R$ hearing thresholds ( $P$-values for frequency were 0.27 at $4 \mathrm{kHz}, 0.001$ at $10 \mathrm{kHz}$, and 0.02 at $16 \mathrm{kHz}$, respectively). injection with $300 \mathrm{mg} / \mathrm{kg}$ sodium salicylate $(p=0.72$ for baseline, $p=0.61$ for day $1, p=0.02$ for day 2 , and $p=$ 0.005 for day 3 ). These findings indicate that treatment with Enbrel $^{\circledR}$ significantly decreased salicylate-induced behaviour associated with tinnitus each day, especially on day 1.

\section{TNFR1/2 gene expression}

Figure 3 shows the expression levels of the TNFR1/ $\mathrm{R} 2$ genes relative to that of $\beta$-actin in the cochlea. The mRNA level of TNFR1 was significantly lower in the treatment than in the control group (0.22 vs. 1.03; MannWhitney U-test, $p=0.0009$ ). The mRNA expression level of TNFR2 also decreased significantly in the treatment group compared with that in the control group (18.61 vs. 66.86; Mann-Whitney U-test, $p=0.01468$ ).

These findings indicate that treatment with Enbrel ${ }^{\circledR}$ significantly reduced the mRNA expression levels of TNFR1 and TNFR2 in the cochlea after i.p. injection with $300 \mathrm{mg} / \mathrm{kg}$ sodium salicylate. Furthermore, according to the findings in the control groups (Figures 4 and 5), i.p. injection with $300 \mathrm{mg} / \mathrm{kg}$ sodium salicylate could alter the mRNA expression level of TNFR1 more than that of TNFR2 (66.86 vs. 1.03; Mann-Whitney U-test, $p=0.0001$ ).

\section{NR2B gene expression}

Figure 5 shows the expression level of NR2B relative to that of $\beta$-actin. The mRNA level of NR2B was significantly lower in the treatment than in the control group (37.9 vs. 224.25; Mann-Whitney U-test, $p=$ 0.01878). These findings indicate that treatment with Enbrel ${ }^{\circledR}$ decreased the mRNA expression level of NR2B in the cochlea after i.p. injection with $300 \mathrm{mg} / \mathrm{kg}$ sodium salicylate.

\section{DREAM gene expression}

Figure 6 shows the expression level of DREAM relative to that of $\beta$-actin. The mRNA level of DREAM was significantly lower in the treatment than in the

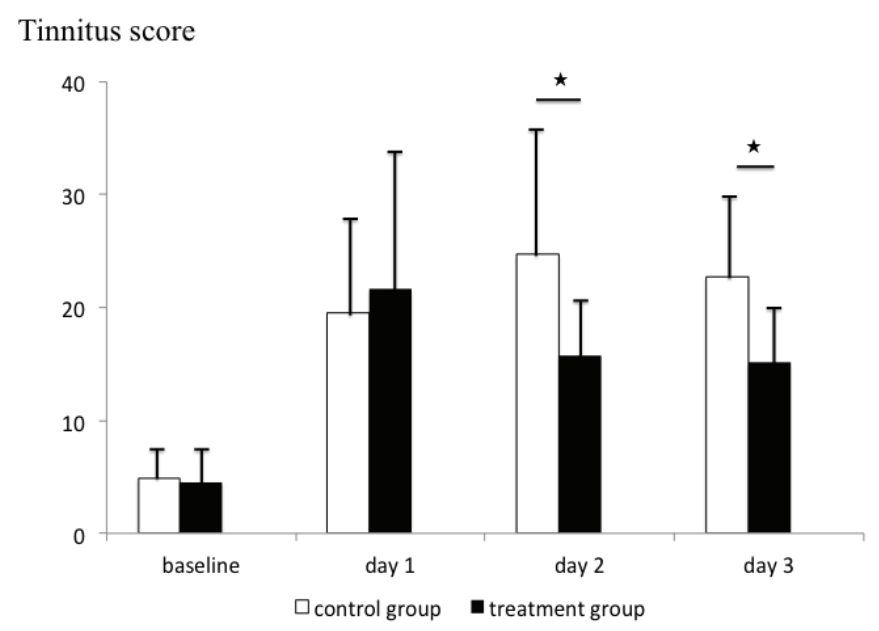

Figure 2: The tinnitus scores for both the groups. Enbrel ${ }^{\circ}$ significantly decreased salicylate-induced tinnitus at day 2 and day 3 after i.p injection with $300 \mathrm{mg} / \mathrm{kg}$ sodium salicylate $(P=0.72$ for baseline, $P=$ 0.61 for day $1, P=0.02$ for day 2 , and $P=0.005$ for day 3 ). 


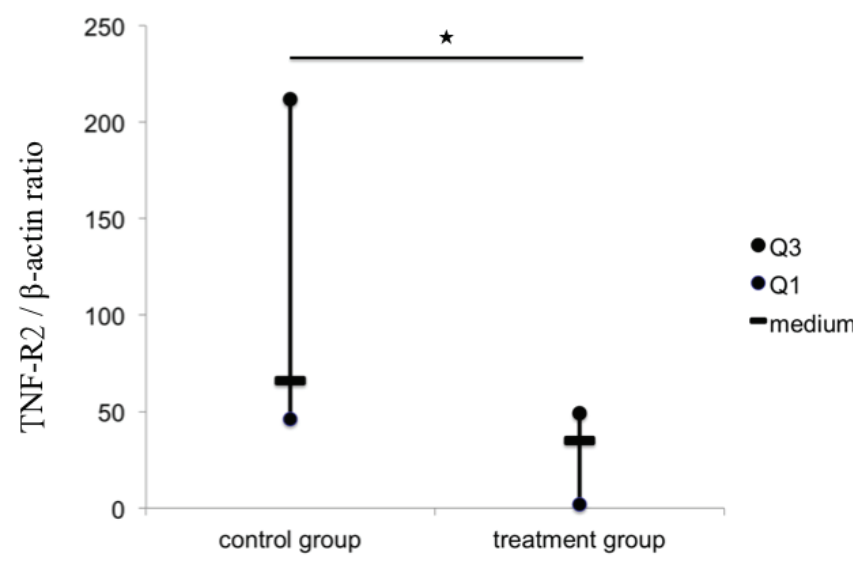

Figure 3: The expression levels of the TNFR1 gene relative to that of $\beta$-actin in the cochlea. The mRNA level of the TNFR1 gene was significantly lower in the treatment than in the control group (0.22 vs. 1.03; Mann-Whitney U-test, $\mathrm{P}=0.0009$ ).

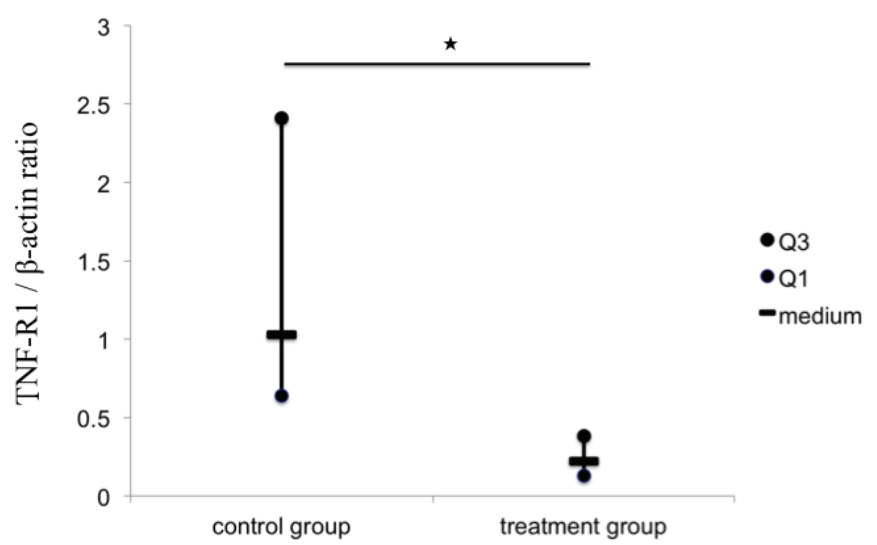

Figure 4: The expression levels of the TNFR2 genes relative to that of $\beta$-actin in the cochlea. The mRNA expression level of the TNFR2 gene decreased significantly in the treatment group compared with the control group (18.61 vs. 66.86; Mann-Whitney U-test, $\mathrm{P}=0.01468$ ).

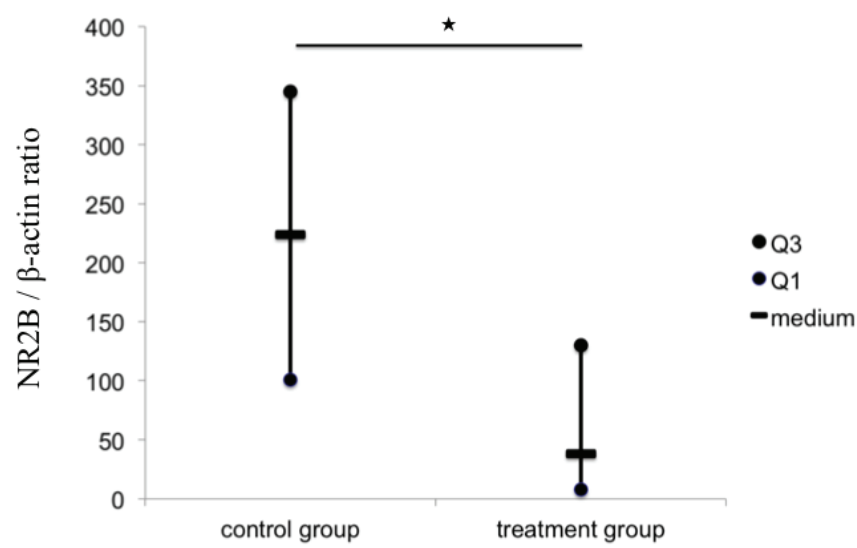

Figure 5: The expression level of the NR2B gene relative to that of $\beta$-actin. The mRNA level of the NR2B gene was significantly lower in the treatment than in the control group (37.9 vs. 224.25; Mann-Whitney U-test, $\mathrm{P}=0.01878$ ).

control group (10.18 vs. 70.04; Mann-Whitney U-test, $\mathrm{p}$ $=0.00988$ ). These findings indicate that Enbre ${ }^{\circledR}$ reduced the mRNA expression level of DREAM in the cochlea after i.p. injection with $300 \mathrm{mg} / \mathrm{kg}$ sodium salicylate.

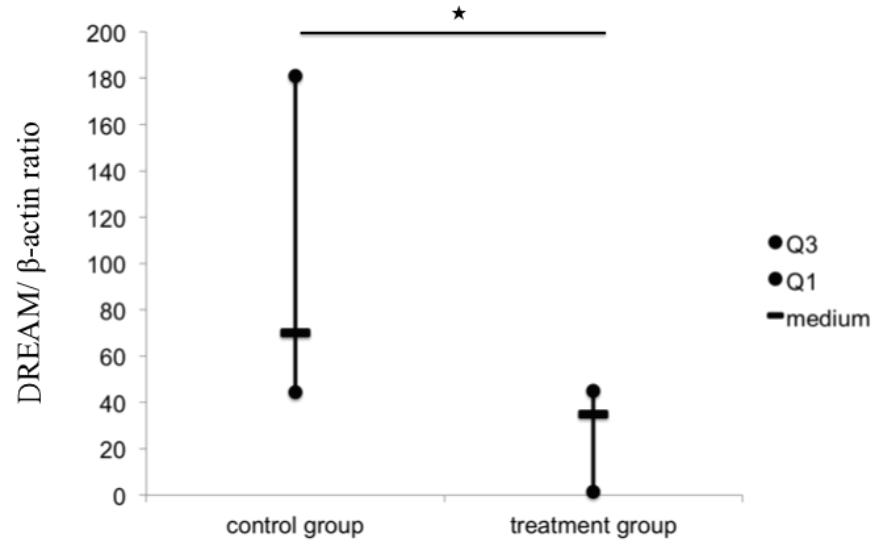

Figure 6: The expression level of DREAM relative to that of $\beta$-actin. The mRNA level of the DREAM gene was significantly lower in the treatment than in the control group (10.18 vs. 70.04; Mann-Whitney U-test, $\mathrm{P}=$ 0.00988).

\section{DISCUSSION}

It is well known that a large dose of aspirin causes reversible hearing loss and tinnitus ${ }^{13}$. The underlying mechanisms for salicylate-induced hearing impairment and tinnitus are numerous. For example, high doses of salicylate might reduce cochlear blood flow and electromotility of outer hair cells ${ }^{14}$. In addition, neuroinflammation and oxidative stress are associated with age-related hearing impairment. Our results showed that Enbrel $^{\circledR}$ significantly decreased salicylate-induced behaviour associated with tinnitus. Further, Enbrel ${ }^{\circledR}$ could reduce the mRNA expression levels of TNFR1/R2, NR2B, and DREAM in the mice cochlea after i.p. injection with $300 \mathrm{mg} / \mathrm{kg}$ sodium salicylate. These findings support the hypothesis that neuroinflammation is a novel mechanism for salicylate-induced tinnitus ${ }^{3-5}$.

TNF- $\alpha$ exerts its biological functions via interactions with two cognate membrane receptors, TNF-R1 and $-R 2^{15,16}$. TNF-R1 contains a conserved protein-protein interaction motif of 80 amino acids, termed the "death domain," which interacts with the adapter molecule TNF receptor-associated protein with death domain (TRADD) ${ }^{17}$. TNF-R2 interacts with TRAF2 and exclusively activates proinflammatory pathways. Although TNF-R2 does not induce apoptosis directly, it can modulate TNF-R1-induced effects, including apoptosis, via crosstalk between TNF-R2 and -R1 signal pathways ${ }^{18}$. In this study, it was observed that i.p. injection with $300 \mathrm{mg} / \mathrm{kg}$ sodium salicylate could increase the mRNA expression level of TNFR1 more than that of TNFR2 in the mice cochlea. However, the salicylate-induced TNFR1 mRNA elevation did not result in cell apoptosis in the cochlea because aspirin only causes reversible hearing loss and tinnitus ${ }^{13}$. Thus, Enbre ${ }^{\circledR}$ was expected to have a beneficial effect on neurodegenerative diseases and neurogenic pain via inducing regulatory macrophages in an $\mathrm{Fc}$ region-dependent manner and blocking downstream inflammation-related signaling pathways $\mathrm{s}^{6,7,11}$. 
Our previous studies indicated that changes in COX and/or NR play a minor role in salicylate-induced tinnitus, although tinnitus was reported to be highly associated with NR activity ${ }^{13}$ and/or its mRNA expression ${ }^{4}$. In fact, interaction between TNF- $\alpha$ and/or IL-1 $\alpha$ and the functions of NR were present $5,18,19$. With respect to NR-related signal pathways, DREAM had a neuroprotective effect against excitotoxic neuronal injury by directly binding to the C0 domain of the NR1 subunit and inhibiting surface expression of NRs and NR-mediated current ${ }^{20}$. Knockdown of DREAM could enhance NMDA-induced toxicity ${ }^{20}$. The results of this study showed that Enbrel ${ }^{\circledR}$ could inhibit both NR2B and DREAM gene expression, which had a reciprocal effect on neural cell function. Here, we conclude that the net effect of this inhibition of DREAM and NR2B by Enbre ${ }^{\circledR}$ is beneficial for tinnitus reduction.

\section{CONCLUSION}

This study showed that the TNFa blocker Enbrel ${ }^{\circledR}$ decreased salicylate-induced behavior associated with tinnitus. This TNF- $\alpha$ blocker might exert its effect via TNF-R directly, in which TNF-R2 plays a more dominant role than TNF-R1 in the cochlea. Further, this TNF- $\alpha$ blocker might reduce salicylate-induced tinnitus indirectly via interaction between TNF-R and the NMDA receptor. Therefore, future research in this field should be directed at conducting clinical trials for treatment with Enbre ${ }^{\circledR}$ in patients with tinnitus.

\section{CONFLICT OF INTEREST}

None declare

\section{ACKNOWLEDGEMENT}

The work was supported by a grant from Ministry of Science and Technology of Taiwan (101-2314-B-002060-MY2) to TCL.

\section{REFERENCES}

1. Langguth $B$, Elgoyhen $A B$. Current pharmacological treatment for tinnitus. Expert Opin Pharmacother 2012;13(17):2495-509.

2. Jastreboff PJ, Brennan JF, Sasaki CT. An animal model for tinnitus. Laryngoscope. 1988;98(3):280-6.

3. Weber C, Arck P, Mazurek B, Klapp BF. Impact of a relaxation training on psychometric and immuneologic parameters in tinnitus sufferers. J Psychosom Res. 2002;52(1):29-33.

4. Hwang JH, Chen JC, Yang SY, Wang MF, Liu TC, Chan YC. Expression of COX-2 and NMDA receptor genes at the cochlea and midbrain in salicylate-induced tinnitus. Laryngoscope. 2011;121(2):361-4.

5. Hwang JH, Chen JC, Yang SY, Wang MF, Chan YC. Expression of tumor necrosis factor- $\alpha$ and interleukin- $1 \beta$ genes in the cochlea and inferior colliculus in salicylate-induced tinnitus. J Neuroinflammation. 2011;8:30-6

6. McRae BL, Levin AD, Wildenberg ME, Koelink PJ, Bousquet P, Mikaelian I, et al. Fc receptor-mediated effector function contributes to the therapeutic response of anti-TNF monoclonal antibodies in a mouse model of inflammatory bowel disease. J Crohns Colitis. 2016;10(1):6976.

7. Vos AC, Wildenberg ME, Duijvestein M, Verhaar AP, van den Brink GR, Hommes DW. Anti-tumor necrosis factor- $\alpha$ antibodies induce regulatory macrophages in an Fc region-dependent manner. Gastroenterology. 2011; 140:221-30.

8. Scott LJ. Etanercept: a review of its use in autoimmune inflammatory diseases. Drugs. 2014;74(12):1379-410.

9. Roh M, Zhang Y, Murakami $Y$, Thanos A, Lee SC, Vavvas DG, et al Etanercept, a widely used inhibitor of tumor necrosis factor- $\alpha$ (TNF- $\alpha$ ), prevents retinal ganglion cell loss in a rat model of glaucoma. PLoS One. 2012;7(7):e40065.

10. Iwatsuki K, Arai T, Ota H, Kato S, Natsume T, Kurimoto S, et al. Targeting anti-inflammatory treatment can ameliorate injury-induced neuropathic pain. PLoS One, 2013;8(2):e57721.

11. Clark IA, Vissel B. Excess cerebral TNF causing glutamate excitotoxicity rationalizes treatment of neurodegenerative diseases and neurogenic pain by anti-TNF agents. 2016;13(1).236.

12. Guitton MJ, Caston J, Ruel J, Johnson RM, Pujol R, Puel JL. Salicylate induces tinnitus through activation of cochlear NMDA receptors. J Neurosci. 2003; 23(9):3944-52.

13. Cazals Y. Auditory sensori-neural alterations induced by salicylate. Prog Neurobiol. 2000;62:583-631.

14. Kakehata S, Santos-Sacchi J. Effects of salicylate and lanthanides on outer hair cell motility and associated gating charge. J Neurosci 1996;16(16):4881-9.

15. Chen G, Goeddel DV. TNF-R1 signaling: a beautiful pathway. Science 2002;296(5573):1634-5

16. Wajant $\mathrm{H}$, Pfizenmaier K, Scheurich P. Tumor necrosis factor signaling Cell Death Differ. 2003;10(1):45-65.

17. Gaur U, Aggarwal BB. Regulation of proliferation, survival and apoptosis by members of the TNF superfamily. Biochem Pharmacol. 2003;66(8):1403-8.

18. McNearney TA, Ma Y, Chen Y, Taglialatela G, Yin H, Zhang WR, et al. A peripheral neuroimmune link: glutamate agonists upregulate NMDA NR1 receptor mRNA and protein, vimentin, TNF-alpha, and RANTES in cultured human synoviocytes. Am J Physiol Regul Integr Comp Physiol. 2010;298(3):584-98.

19. Nakazawa T. Mechanism of $\mathrm{N}$-methyl-D-aspartate-induced retina ganglion cell death. Nippon Ganka Gakkai Zasshi 2009;113:1060-70.

20. Kalev-Zylinska ML, Symes W, Young D, During MJ. Knockdown and overexpression of NR1 modulates NMDA receptor function. Mol Cell Neurosci. 2009;41(4):383-96. 